\title{
Ten minutes with Dr lain Wallace, Medical Director, NHS Louisa Jordan Hospital, Scottish Events Campus (SEC), Glasgow
}

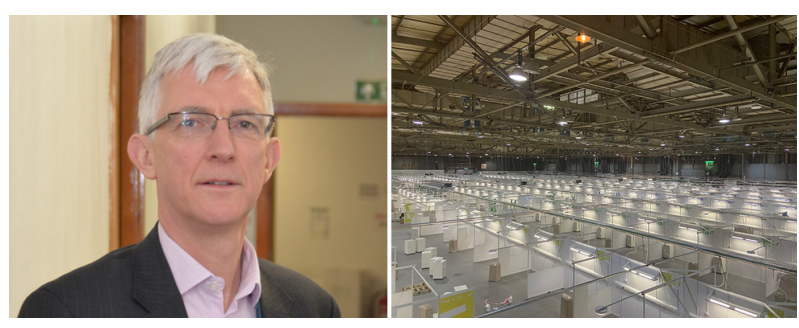

FIRST AND FOREMOST, ARE THERE ANY KEY LEADERSHIP MESSAGES YOU WANT TO GET OUT TO OUR READERSHIP?

One is about leadership being about relationships with people, and the need to treat the people you are leading with kindness. I think it's incumbent on leaders to try hard to understand why people are acting as they are-we manifest anxiety and stress differently—and to make allowances for that.

In addition, at a time of crisis, it's reasonable and necessary to draw from whatever reservoir of goodwill you have built up with people before the crisis, but remember you can't use it up completely and you will need to refill it as soon as, and whenever, you can.

Next, never stop listening and learning. Even after 20 years at this, there are still new situations and new learning for me. That's good.

Finally, don't be frightened to express a contrary opinion. We know that under stress our focus will tend to narrow down, but it's important for us all to keep our horizons as wide as possible. The wider our horizons, the more chance there is of seeing unexpected things coming towards us, or expected things coming from unexpected directions.

\section{TELL US A LITTLE BIT ABOUT YOUR LEADERSHIP ROLE AND HOW IT IS CHANGING AS A RESULT OF THE PANDEMIC?}

Until recently I had been in semi-retirement after 20 years of Medical Director roles. I have been doing some strategic planning with West of Scotland Health Boards, some executive coaching, and after Dame Clare Marx went to become chair of the General Medical Council, I was Interim Chair of the Faculty of Medical Leadership and Management until December 2019. At the end of March 2020, I was asked to take on this role as Medical Director of NHS Louisa Jordan, the temporary hospital being developed for Scotland's COVID-19 pandemic response, which is located within the Scottish Events Campus in Glasgow. It's a big challenge due to the nature of the facility, though in some ways I have returned to familiar 'Medical Director territory'. The aim is to build a new hospital-planned to be a stepdown facility not an ICU— to be ready by mid-April. That means going from an exhibition and conference centre to a functioning 1000-bed hospital in 18 days. I have been involved in the specification of the building - the construction of which is going welland have a major role looking at the clinical workforce, clinical governance, pathways of care and infection prevention and control processes. It's massively exciting. It's been a while since I was in clinical practice, and with the pandemic I was starting

\section{Biography}

lain Wallace studied Immunology and Medicine at the University of Glasgow and later gained an MBA from Strathclyde Graduate Business School. He practised as a GP principal for 10 years before being appointed Medical Director of Greater Glasgow Primary Care Trust in 1999. In 2005 he became the Associate Medical Director for the Women and Children's Directorate in Greater Glasgow and Clyde and for a time combined this role with being Interim Medical Director of NHS Quality Improvement Scotland. He was appointed as Medical Director of NHS Forth Valley in 2010 before moving to the same role in NHS Lanarkshire in June 2013. Following his retirement in October 2018, lain became medical advisor to the West of Scotland Regional Planning Team and in March 2020 he took up the role of Medical Director, NHS Louisa Jordan. lain has also trained as an executive coach.

He has been chair of the Scottish Association of Medical Directors and the Faculty of Medical Leadership and Management. He is also an honorary professor in the School of Health and Life Sciences, Glasgow Caledonian University, and an honorary clinical associate professor in the College of Medicine, Veterinary and Life Sciences, University of Glasgow.

to feel I wasn't contributing, so I was delighted to be asked to take this on. In one sense I hope the hospital is never even used; whether it will be will depend on how things evolve, whether the current social interventions, such as distancing, ameliorate the predicted surge in cases, and what the longer term compliance is with any ongoing public health measures.

\section{WHAT EVENTS IN YOUR PAST EXPERIENCE ARE MOST INFORMING YOUR LEADERSHIP IN THIS PANDEMIC?}

Every situation is different, but I have experience of planning and building two new hospitals in my career, so I am used to working with architects and builders on hospital design and construction. I was Medical Director of a children's hospital during the 2009 influenza H1N1 pandemic, which did not affect us too badly, but it did mean I was involved in all the planning and response processes, as well as subsequent updates in pandemic flu planning. Of course, these were all done on paper! Maybe more live exercises between then and now would have been good, but, of course, that would have been quite disruptive to day-to-day work; for example, the current response to the COVID-19 pandemic has required 125 people from all across NHS Scotland to work flat out for 3 weeks on the planning and preparation phase of this hospital. Partly because it's so hard to make the time for planning ahead when you are really busy, it will be really important to capture the learning from this pandemic. We won't make all the right decisions, it's just not possible, so we need to learn from this to inform the future. We also need doctors and other professions in training, and younger consultants, to be involved in leading and managing the response at tactical 
and strategic level, to ensure that we have some organisational learning that endures long after people like me are gone.

\section{WHAT ARE YOU FINDING THE BIGGEST CHALLENGES?}

I think the biggest one is turning the high-level aims into reality into such a short time. Another is managing the tension between autonomy, trust, oversight and delivery, meaning that you need self-managing teams to get much of this work done quickly, but then you need to get information back, on their progress and problems, without overloading anyone. Part of the trick is to walk through patient journeys, mapping out how they will work, identify possible problems before anything is put into practice and so on, working out what to put in place and where. This is relatively harder than in an established hospital, but there is also an opportunity to do it differently because everything is new.

\section{ANY PARTICULAR SURPRISES?}

Lots of small things, nothing hugely unexpected. And surprises can be good. I've seen groups of clinicians, who were previously very independent of each other, coming together to create networks for mutual aid and support. We are also seeing construction companies that are rivals in 'normal times' working together at the moment, acting as a single team for the common good. It's great to see.

\section{ARE YOU SEEING ANY BEHAVIOURS FROM COLLEAGUES THAT ENCOURAGE OR INSPIRE YOU?}

Collaboration and utter selflessness, lots of people willing to work weekends and evenings to get this hospital ready, and people really embracing innovation. And there are lots of 'modest heroes', for example people who have worked in military hospitals, who have a very different mindset, one that is very awe-inspiring.

\section{HOW ARE YOU MAINTAINING KINDNESS AND COMPASSION?}

Maybe ask others! I am trying my best... One thing that is important for me is that I have never had much sense of position power, I try to relate to people as non-hierarchically as possible. I learned that from my dad; he was a D-day veteran who started as a garage mechanic and ended up running a Ford dealership. No matter who you were or what you did, he treated everyone with the same interest and respect. I really believe that people are of equal value whatever they do. In this project, the builders say they provide the brawn and the docs the brains, but it's clear the builders bring enormous skill and thought and value.

\section{ARE THERE ANY IDEAS OR READINGS THAT YOU FIND HELPFUL FOR INSPIRATION AND SUPPORT THAT YOU WOULD RECOMMEND TO OTHERS?}

I read a short article (prepublication) last week by Brigadier Tim Hodgetts, setting out his approach to people and leadership. ${ }^{1}$
Though it's derived from a military setting, his principles are very resonant; walking the floor, being close to people on the ground. That will need some thought to implement in the COVID-19 pandemic - do I use up PPE visiting staff on wards with infected patients, or do I find other ways to meet staff coming in and out of the wards? But it's got to be the right thing to be highly visible and highly aware of what clinicians - and all who support them on the wards-are going through. I hope Brigadier Hodgetts' article is going to be published soon and we can direct people to it.

The other really useful resource is something I use in coaching. It's called 101 Coaching Strategies and Techniques, by Gladeana McMahon and Anne Archer, ${ }^{2}$ and it has lots of helpful ideas. Even in the pandemic, we are still going to need to employ a coaching style of leadership as often as the situation permits; it's more engaging, it builds capability, and we have a long road ahead. To succeed, we will need more leaders to develop, and we may as well start now.

\section{WHAT ARE YOU LOOKING FOR FROM YOUR LEADERS?}

Clarity of purpose, constructive challenge, support, and the sense that they are 'constantly there', but are acting to facilitate me, and are giving me free rein, to solve my problems.

Iain Wallace, ${ }^{1}$ Anthony Robert Berendt ${ }^{2}$

${ }^{1}$ NHS Louisa Jordan Hospital, NHS Scotland, Glasgow, UK

${ }^{2}$ Department for Continuing Education, University of Oxford, Oxford, UK

\section{Correspondence to}

Dr Anthony Robert Berendt, Department for Continuing Education, University of Oxford, Oxford, UK; a.berendt@ntlworld.com

Twitter Anthony Robert Berendt @tony_berendt

Funding The authors have not declared a specific grant for this research from any funding agency in the public, commercial or not-for-profit sectors.

Competing interests None declared.

Patient consent for publication Not required.

Provenance and peer review Not commissioned; internally peer reviewed.

Data availability statement No data are available.

(c) Author(s) (or their employer(s)) 2020. No commercial re-use. See rights and permissions. Published by BMJ.

\section{Check for updates}

To cite: Wallace I, Berendt AR. BMJ Leader 2020;4:147-148.

Received 17 April 2020

Accepted 22 April 2020

Published Online First 6 May 2020

BMJ Leader 2020;4:147-148.

doi:10.1136/leader-2020-000266

\section{REFERENCES}

1 Hodgetts BTJ. "Transferable lessons for clinical leadership of a field hospital". BMJ Opinion in press 2020.

2 McMahon G, Archer A. 101 Coaching Strategies and Techniques. Routledge, London and New York, 2010 